Research article

\title{
Presence of papillomavirus sequences in condylomatous lesions of the mamillae and in invasive carcinoma of the breast
}

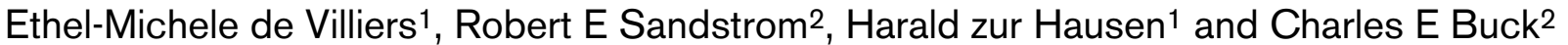

\author{
${ }^{1}$ Division for the Characterization of Tumorviruses, Deutsches Krebsforschungszentrum, Heidelberg, Germany \\ 2Lower Columbia Pathologists, Longview, Washington, USA \\ Corresponding author: Ethel-Michele de Villiers, e.devilliers@dkfz.de
}

Received: 10 May 2004 Revisions requested: 9 Jul 2004 Revisions received: 7 Aug 2004 Accepted: 7 Sep 2004 Published: 22 Oct 2004

Breast Cancer Res 2005, 7:R1-R11 (DOI 10.1186/bcr940)

(C) 2004 de Villiers et al.; licensee BioMed Central Ltd.

This is an Open Access article distributed under the terms of the Creative Commons Attribution License (http://creativecommons.org/licenses/by/

2.0), which permits unrestricted use, distribution, and reproduction in any medium, provided the original work is properly cited.

\begin{abstract}
Background Viruses including Epstein-Barr virus (EBV), a human equivalent of murine mammary tumour virus (MMTV) and human papillomavirus (HPV) have been implicated in the aetiology of human breast cancer. We report the presence of HPV DNA sequences in areolar tissue and tumour tissue samples from female patients with breast carcinoma. The presence of virus in the areolar-nipple complex suggests to us a potential pathogenic mechanism.
\end{abstract}

Methods Polymerase chain reaction (PCR) was undertaken to amplify HPV types in areolar and tumour tissue from breast cancer cases. In situ hybridisation supported the PCR findings and localised the virus in nipple, areolar and tumour tissue.
Results Papillomavirus DNA was present in 25 of 29 samples of breast carcinoma and in 20 of 29 samples from the corresponding mamilla. The most prevalent type in both carcinomas and nipples was HPV 11 , followed by HPV 6 . Other types detected were HPV 16, 23, 27 and 57 (nipples and carcinomas), HPV 20, 21, 32, 37, 38, 66 and GA3-1 (nipples only) and HPV 3, 15, 24, 87 and DL473 (carcinomas only). Multiple types were demonstrated in seven carcinomas and ten nipple samples.

Conclusions The data demonstrate the occurrence of HPV in nipple and areolar tissues in patients with breast carcinoma. The authors postulate a retrograde ductular pattern of viral spread that may have pathogenic significance.

Keywords: areolar tissue, breast carcinoma, papillomavirus

\section{Introduction}

Breast cancer is the most frequently diagnosed cancer among women in the USA, and the incidence of breast carcinoma has increased by more than $40 \%$ over 25 years [1]. The aetiology of breast cancer remains unknown. Many risk factors have been associated with the pathogenesis of this disease, including family history, hormones, cigarette smoking and alcohol consumption [2-7]. Hormones, cigarette smoking and family history have also been demonstrated to enhance infections with papillomaviruses, mainly the highrisk human papillomavirus (HPV) types involved in the aetiology of cervical carcinoma [8].

Viral infection as an aetiological factor has been addressed in other studies. The data obtained from studies investigating the presence of viral sequences in breast cancer biopsies and cell lines have been controversial. A role for herpes viruses, and specifically Epstein-Barr virus (EBV), in the aetiology of this cancer has been questioned $[9,10]$.
A human equivalent of the murine mammary tumour virus (MMTV) has been described in breast tumours, as well as in breast cancer cell lines [11]. These results have been questioned and negated by others (R Schmidt and $\mathrm{H}$ zur Hausen, unpublished results) [12]. Immortalisation of normal breast epithelial cells by the HPV types HPV 16 and HPV 18 [13] has been used to study the functions of the viral early genes E6 and E7 in different cellular pathways [14-18]. However, the presence of HPV in malignant tumours of the breast has been controversial. Several studies reported positive results [19-25], whereas others reported negative results [26-28]. In the present study we report the presence of HPV DNA in biopsy samples from mammary carcinomas, as well as these viral sequences in the tissue of the corresponding mamilla. 


\section{Materials and methods Samples and DNA extraction}

Samples from breast tumour tissue for the HPV analysis were supplied by two of the authors (RES and CEB). The 29 cases used for the retrospective study and demonstration of papillomavirus sequences were selected from routine mastectomy specimens undertaken in a course of treatment for carcinoma of the breast. Case selection was based on the availability of adequate nipple and tumour tissue from the same patient and the presence of histological features suggestive of HPV infection in nipple and areolar sections. The patients, all female, ranged in age from 30 to 88 years, with an average age of 61.3 years. Twelve tumours arose in the right breast and 17 in the left. Five tumours were subareolar and 24 were located at a distance from the nipple and areola. Tumours ranged in size from 6 $\mathrm{mm}$ to $15 \mathrm{~cm}$. One patient received cytoxan chemotherapy before surgery. In all other cases primary treatment was surgical as represented by the specimen. One patient had undergone contralateral mastectomy ten years earlier for a localised breast cancer, which was judged clinically and pathologically to represent a separate primary tumour. Among the 29 patients there were three with remote histories of malignancy without evidence of recurrence (one cutaneous malignant melanoma, one renal cell carcinoma and one soft-tissue malignancy). One patient had undergone hysterectomy for high-grade cervical dysplasia. There were no patients with documented cervical carcinoma. No patients were immune-impaired or immunosuppressed.

Formalin-fixed paraffin-embedded samples from both the nipple $(n=29)$ and the carcinoma of the breast $(n=29)$ from the same patient were sectioned, and the total DNA was extracted from each sample. Great care was taken during sectioning to avoid any contamination between samples. Two different individuals sectioned the blocks in several small random groups at different time intervals over a period of one week. The microtome was cleaned thoroughly and exposed to ultraviolet between samples; in addition, new blades were used for each sample. Deparaffinisation was performed by rotation overnight in $1 \mathrm{ml}$ of xylene, followed by centrifugation and subsequent removal of the supernatant. This step was repeated twice (each for one hour) with fresh xylene. The xylene was in turn removed by rotation in $1 \mathrm{ml}$ of $100 \%$ ethanol for one hour followed by centrifugation and subsequent replacement of the supernatant with $90 \%$ ethanol for $45 \mathrm{~min}$, and repeated by steps of $80 \%$ ethanol for $45 \mathrm{~min}$ and $70 \%$ ethanol for 45 min. Samples were freeze-dried, and total cellular DNA was extracted as described previously [29]. The DNA was digested with Proteinase $\mathrm{K}$ and subjected to extraction with phenol followed by extraction with chloroform/isoamyl alcohol. The extracted DNA was precipitated with ethanol and the pellet was resuspended in $10 \mathrm{mM}$ Tris $/ \mathrm{HCl}, \mathrm{pH} 8.0$.

\section{PCR analysis and cloning}

DNA (50-100 $\mu \mathrm{g})$ of each sample was amplified by polymerase chain reaction (PCR). The quality of the DNA obtained from the fixed samples was controlled by amplification with primers to detect the $\beta$-actin gene [30]. The primers RS42 and KM29 were initially used to amplify the 536-base-pair fragment of the $\beta$-actin gene. If this size of fragment could not be amplified, the primers PC03 and PC04 were used to amplify the 110-base-pair (bp) fragment of the $\beta$-actin gene. Papillomavirus sequences were amplified by three different methods, each targeting highly conserved regions within the $L 1$ open reading frame of papillomaviruses. These included the GP5+/GP6+ primers [31], the CP primers using modified conditions as previously described [32] and the FAP primers [33]. All three primer combinations are routinely used on individual samples tested in our laboratory. We initially modified the PCR conditions for each described method to include the amplification of the largest number of individual HPV types possible. Cloned DNA of each known HPV type was used to optimise these conditions. Amplification with the GP primers was performed in $2 \mathrm{mM} \mathrm{MgCl}_{2}$ using 40 cycles with an annealing temperature of $40^{\circ} \mathrm{C}$. The expected size of the amplicon was 140-150 bp. The expected size with the FAP primers is 480 bp after 45 cycles in $3.5 \mathrm{mM} \mathrm{MgCl}_{2}$ and an annealing temperature of $50^{\circ} \mathrm{C}$. The nested amplification approach with the CP primers results in an amplicon size of 370-400 bp. The initial amplification was performed in $2 \mathrm{mM} \mathrm{MgCl}_{2}$ and 40 cycles at $50^{\circ} \mathrm{C}$ annealing temperature, after which an aliquot was re-amplified with nested primers but with the same PCR conditions. All amplicons were eluted after gel electrophoresis, purified and cloned. At least ten fragments of each amplicon were sequenced. Sequencing was performed with either the Sequenase 2.0 DNA Sequencing Kit (USB, Cleveland, $\mathrm{OH}$ ) or an $\mathrm{ABI}$ Model Sequencer with Big Dye Terminator chemistry (Perkin Elmer Applied Biosystems Division, Dreieich, Germany). All precautions were taken to avoid contamination before or during extraction of the DNA from the embedded formalinfixed samples. After initial results had been obtained, a second sectioning was performed on the same embedded samples and DNA was again extracted to ensure that no contamination had taken place during the first round of experiments. This second round of analyses was performed in different rooms and by different individuals.

\section{Sequence analysis}

Sequences were compared with all available data banks with the aid of the Husar software package (Deutsches Krebsforschungszentrum).

\section{In situ hybridisation}

In situ hybridisation was performed as described by Kawase and colleagues [34]. Papillomavirus probes were digoxigenin-labelled by PCR in accordance with the 
manufacturer's instructions (PCR DIG Probe Synthesis Kit, catalogue no. 1636090; Roche, Mannheim, Germany). The FAP primers were used to label HPV 6 and HPV 11 DNA and the CP primers to label HPV 16 DNA. Denaturation was performed in a Biozym cycler for $5 \mathrm{~min}$ at $95^{\circ} \mathrm{C}$ followed by hybridisation overnight at $37^{\circ} \mathrm{C}$ under stringent conditions as described previously [35]. This was followed by washing with solutions in accordance with instructions in the Genpoint Kit (catalogue no. K0620; Dako, Hamburg, Germany). Anti-digoxigenin-AP antibodies (anti-digoxigenin-AP, Fab fragments, catalogue no. 1093274; Roche), blocking reagent (catalogue no. 1096176; Roche) and Nitro Blue Tetrazolium/5-bromo-4-chloroindol-3-yl phosphate (catalogue no. 1681451; Roche) were applied for visualisation of the signals. Sections from each sample were used for in situ hybridisation. Reading of the samples was blinded and performed by one of us $(\mathrm{HzH})$.

\section{Results}

Nipple specimens were reviewed and selected by two of us (CEB, RES) for histological features consistent with human papillomavirus infections. Features identified included epithelial hyperplasia, hypergranulosis, parakeratosis, and distorted nuclear shape associated with nuclear clearing and pyknosis suggestive of koilocytosis. In addition, squamous metaplasia of lactiferous ducts and shedding of metaplastic cellular elements into lactiferous ducts and sinuses were noted (Fig. 1). In addition to the 29 invasive carcinomas, ductal carcinoma in situ was identified in lactiferous ducts in four samples and small benign papillomas were present in three samples. Most invasive carcinoma samples (18 of 29) displayed a duct cell carcinoma pattern (Table 1). Other types included medullary carcinoma (five cases), tubular carcinoma (three cases), lobular carcinoma (two cases) and mucinous carcinoma (one case). DNA extracted from the samples taken from the nipple and the corresponding carcinoma of each breast (29 pairs) was analysed by PCR for the presence of papillomavirus sequences. The quality of the DNA was controlled by amplification of the $\beta$-actin gene. The 536 -base-pair fragment of this gene was amplified in 47 of 58 samples. The 110-base-pair fragment was amplified in the remaining 11 samples (Table 2). Intact papillomavirus particles are resistant to degeneration. Extraction of DNA from fixed tissue can harbour intact viral genomes even under conditions in which the cellular DNA has been degraded. The three different methods used for amplification of the papillomavirus DNA were chosen to ensure amplification of all known papillomavirus types, as well as putative new types. All three primer combinations (GP, CP and FAP) are routinely used on individual samples tested in our laboratory. We initially modified the PCR conditions for each described method to include the amplification of the largest number of individual HPV types possible. Cloned genomic DNA of each known HPV type was used to optimise these conditions. The GP primers have been designed to amplify the majority of papillomavirus types associated with mucosal lesions. The FAP primers, in contrast, were initially designed to amplify the majority of papillomavirus types associated with cutaneous lesions. The amplicon size described is $480 \mathrm{bp}$, but in our hands smaller fragments identified as papillomavirus sequences (after cloning and sequencing) were also generated, depending on the HPV type. The CP primers were originally designed to amplify all the epidermodysplasia verruciformis-associated HPV types, but under modified conditions a large spectrum of mucosal types are amplified as well. Combining the three methods with the modified PCR conditions allows us to amplify all known HPV types with more or less equal efficiency. The amplicons generated, using any of the described methods, often constitute cellular sequences depending on the viral load of the sample.

Normal breast and areolar tissue was not available for use as control samples. The described methods of testing have been used routinely in our laboratory over several years in the analyses of tissues from a large variety of organs. We have analysed large numbers of samples from benign and malignant tumours of the oesophagus, head and neck and skin, as well as normal skin tissue for the presence of papillomavirus DNA with identical methods. HPV positivity varied depending on the type of tumour and normal tissue [29,36-38] (E-MdV, unpublished data). The present study describes the first series of tissue of the breast analysed in our laboratory for the presence of papillomavirus DNA. Sequence analyses showed that $25(86 \%)$ of the breast carcinoma samples and 20 (69\%) of the samples from the mamilla harboured papillomavirus sequences. The results for each sample using each of the primer combinations are presented in Table 2. Only one pair of samples were both negative for HPV DNA. HPV DNA was present in 17 (59\%) pairs of samples, namely nipple as well as carcinoma, whereas papillomavirus DNA was detected only in the carcinomatous tissue in eight cases (28\%) and only in the nipple in three cases (10\%) (Table 3). HPV 11 DNA was present in both carcinoma and nipple samples in seven cases, HPV 6 in one case and HPV 57 in two cases. The most prevalent HPV types were HPV 11 (19 carcinomas and 8 nipples) followed by HPV 6 (7 carcinomas and 6 nipples) (Table 4). Other HPV types detected were HPV 16 (2 carcinomas and 3 nipples), HPV 57 (2 carcinomas and 3 nipples), HPV 27 (2 carcinomas and 4 nipples), HPV 66 (2 nipples), candHPV 87 (4 carcinomas), HPV 37 (4 nipples) and the putative new HPV type DL250 (HPV 9-related) in two carcinomas. HPV types detected in single samples of the nipple were HPV 20, 21, 23, 32, 38 and GA3-1 (HPV 8-related) and HPV 3, 15, 23, 24 and DL473 (HPV 15related) in carcinoma samples. Multiple HPV types were demonstrated in eight carcinomas (24\%) and ten nipple (34.5\%) samples. 

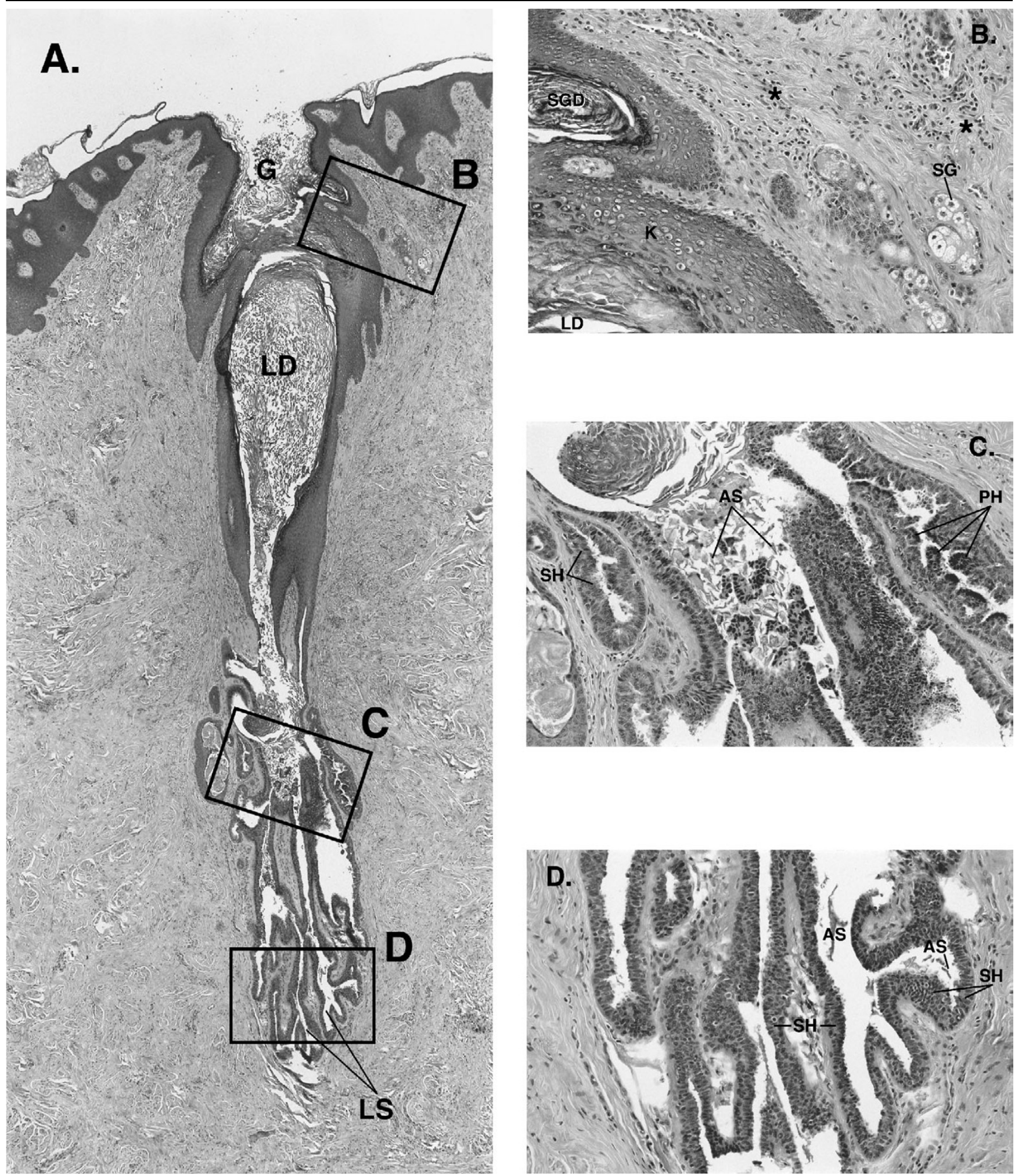

Histological features of the carcinomatous breast (magnification $\times 100)$. Detailed histology of $(a)$ is seen in $(b-d)$. AS, anucleate squames; asterisks, interstitial lymphocytic infiltrates; G, galactophore; K, keratin; LS, lactiferous sinus; LD, lactiferous duct; SG, sebaceous gland (tangenial cut); SGD, sweat gland duct; $\mathrm{SH}$, simple epithelial hyperplasia; $\mathrm{PH}$, papillary epithelial hyperplasia. 
Table 1

\begin{tabular}{|c|c|c|c|}
\hline Carcinoma type & Location & Number tested & HPV DNA positive \\
\hline \multirow[t]{2}{*}{ Invasive ductal } & Carcinoma & 18 & 16 \\
\hline & Nipple & & 11 \\
\hline \multirow[t]{2}{*}{ Medullary } & Carcinoma & 5 & 4 \\
\hline & Nipple & & 3 \\
\hline \multirow[t]{2}{*}{ Tubular } & Carcinoma & 3 & 3 \\
\hline & Nipple & & 3 \\
\hline \multirow[t]{2}{*}{ Lobular } & Carcinoma & 2 & 1 \\
\hline & Nipple & & 2 \\
\hline \multirow[t]{2}{*}{ Mucinous } & Carcinoma & 1 & 1 \\
\hline & Nipple & & 1 \\
\hline \multirow[t]{2}{*}{ Total carcinoma } & Carcinoma & 29 & $25(86 \%)$ \\
\hline & Nipple & & $20(69 \%)$ \\
\hline
\end{tabular}

HPV, human papillomavirus.

In situ hybridisation was performed on all samples that had previously been positive by PCR amplification for HPV 6, HPV 11 or HPV 16. Positive signals were clearly distinguishable from the surrounding negative tissue (Fig. 2). All carcinoma samples that had been negative for one of these three HPV types by PCR were also subjected to in situ hybridisation with each of the respective labelled HPV probes. No positive hybridisation signal was observed in any of these samples. In situ hybridisation supported the presence of HPV 6, 11 and 16 in nipple and areolar samples and in all tumour tissue in which these type-specific HPV sequences were detected by PCR analysis.

\section{Discussion}

The ubiquitous distribution of papillomavirus infections of the skin and genital and oral mucosa has been documented [39-41]. Infection with specific papillomavirus types has been shown to be a necessary but not sufficient cause in the pathogenesis of malignant genital tumours. The malignant tumours generally develop after long latency periods during which additional cellular modifications occur within the infected cell [8]. The E6 and E7 genes of the most prevalent high-risk HPV types, HPV 16 and HPV 18, modulate cellular pathways, thereby regulating proliferation and cell survival [8,42]. In contrast, the E6 and E7 proteins of the low-risk types, HPV 6 and HPV 11, do not influence these cellular pathways in the same manner, although they have occasionally been demonstrated in premalignant and malignant tumours. Additional cofactors are probably needed to modulate cellular proteins so as to immortalise and transform the infected cells [8]. The mechanism through which other HPV types, mainly associated with cutaneous lesions, might be involved in the pathogenesis of

\section{Figure 2}
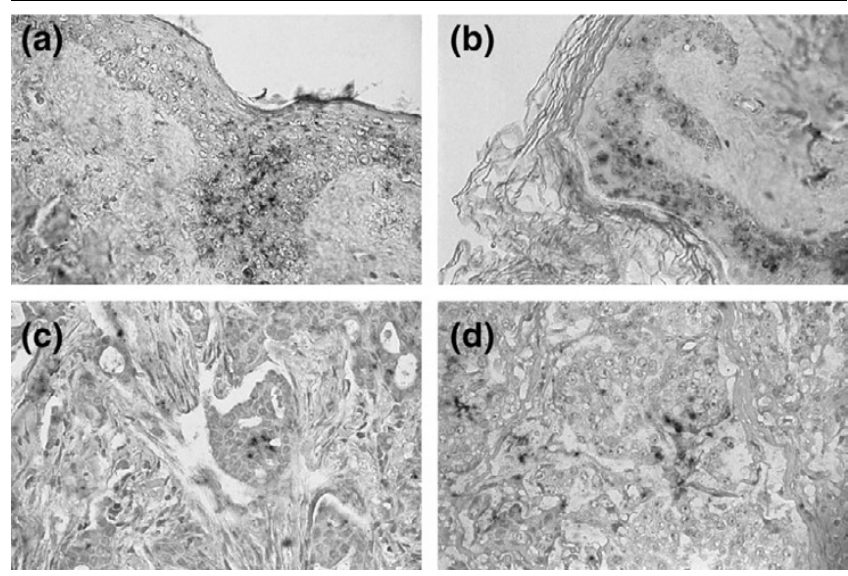

Papillomavirus sequences detected by in situ hybridisation. (a) Case 10012, in the nipple epithelium (magnification $\times$ 40). (b) Case 10041, in the nipple epithelium (magnification $\times 40$ ). (c) Case 10012, in tumour tissue (magnification $\times 100$ ). (d) Case 10014, in tumour tissue (magnification $\times 100$ ).

tumours has received little attention. However, preliminary data indicate that several molecular pathways are probably followed, depending on the HPV type involved [43].

The detection of papillomavirus infections in tissues largely depends on the method used. Described methods vary greatly in their sensitivity and specificity. The HPV types HPV 6, 11, 16, 18, 31, 33, 35, 39, 52 and 58 are frequently associated with genital lesions and are therefore most often targeted for HPV detection. Tests to demonstrate any of the 96 characterised HPV types in tissues require extensive analyses, including the sequencing of cloned amplim- 
ers. Most published studies therefore used methods restricted to the detection of specific, single, or combinations or groups of HPV types. The use of type-specific primers may increase the number of positive samples but is biased with regard to the HPV types involved, because other HPV types present cannot be detected.

The present study investigated breast samples by using DNA PCR amplification of two conserved regions within the $L 1$ open reading frame of the papillomavirus genome. Two of the primer combinations used (CP and GP primers) amplify an overlapping region within the L1 open reading frame. By using all three primer combinations to amplify the DNA of a single sample we are able to detect all known HPV types and also putative new HPV types. In addition, the cloning of the amplified product, in combination with sequencing of the cloned inserts, allows us to distinguish individual HPV types present in one sample, including multiple infections in one sample. Studies applying the techniques described here have demonstrated a larger spectrum of papillomavirus types associated with different types of benign and malignant tumours and argue that the historical grouping into 'mucosal' and 'cutaneous' HPV types can no longer be upheld [44]. We are not aware of any study outside our group that has analysed tissues for the presence of infection by any HPV types as extensively as the study described here.

Other investigators have analysed nipple and areolar specimens for the presence of HPV DNA. HPV 6/11 was detected in one of 20 papillomas of the nipple, whereas ten nipple duct adenomas were negative [45] and seven lowrisk and high-risk HPV types were not present in 20 cases of Paget's disease of the nipple [46]. Single cases of papillomas of the nipple resembling condylomata acuminata harboured HPV 6 DNA [47] and HPV 41 DNA [48]. Reports on the detection of HPV 16, HPV 18 and/or HPV 33 DNA in breast carcinoma samples range between $11 \%$ and $68 \%$ positivity [19-25]. The present study detected HPV 16 DNA in $7 \%$ of the carcinoma and in $10 \%$ of the nipple samples. The only other high-risk HPV type, HPV 66, was present in two samples from the nipple. The reasons for the differences in published reports are unclear, but may be attributed to numbers of samples tested, methodological differences or the demographics of the samples tested. In contrast, several other studies failed to demonstrate HPV sequences in tumours of the breast: all of 15 papillomas and 28 breast carcinoma samples were negative for HPV 6, 16 and 18 DNA [26], no HPV 16 and HPV 18 DNA could be detected in 26 fine needle aspirates and four breast carcinoma biopsies [28], and no HPV DNA was found in 80 samples of breast carcinomas [27]. HPV 16 and HPV 18 oncogenes immortalise normal human mammary cells under in vitro conditions [14-18]. It is unclear whether these data truly represent the in vivo situation.
The present study detected papillomavirus sequences in $86 \%(25 / 29)$ of the breast carcinoma samples and $69 \%$ (20 of 29) of the nipple samples. HPV 6 and HPV 11 infections were most prevalent in our collection of samples. Either of the two HPV types was present in 20 of 29 (69\%) of the breast carcinoma biopsies and in 12 of $29(41 \%)$ of the samples of the mamilla. We detected the simultaneous presence of more than one HPV type in about one-third of the samples. HPV types associated with mucosal lesions, and also several associated with skin lesions, were detected. HPV 27 and HPV 57 are closely related HPV types. HPV 27 is very frequently found in cutaneous warts, whereas HPV 57 has been demonstrated in mucosal and cutaneous lesions [49]. Several other HPV types found in the breast samples have historically been associated with the rare hereditary disease epidermodysplasia verruciformis but have more recently been shown in nonmelanoma skin cancers and their precursors in both immunosuppressed and immunocompetent patients [44].

The confirmation of PCR-derived evidence of HPV sequences in nipple, areolar and tumour tissue by in situ hybridisation in our hands lends substantive support to the conjecture that viral sequences are present and not an artefact in the tissues we have examined. The absence of HPV DNA in several samples, as well as the detection of different HPV types in the carcinoma versus the nipple of the same patient, might be attributed to the viral load at the time of sampling in combination with the sensitivity of the tests performed. The tissue sections also harboured unaffected tissue, leading to the dilution of virus-containing cells. In addition, the amplification of viral DNA by PCR with degenerate or consensus primers will detect replicating viral sequences and is not sensitive enough to detect all individual HPV types with equal sensitivity in a mixed population of cells. The in situ hybridisation technique is also less sensitive and will not detect a single viral genome copy per cell.

HPV 6 and HPV 11 are regarded as low-risk HPV types because they have only rarely been demonstrated in premalignant or malignant tissue, and the early genes E6 and E7 do not immortalise primary keratinocytes in vitro [50]. HPV 6 DNA has been found in carcinomas [51,52] and giant condylomas (Buschke-Löwenstein tumours) [53,54]. The molecular mechanism by which these low-risk HPV types induce or participate in the transformation of cells has not been resolved. Duplications of the long control region [5457], minimal sequence dissimilarities $[58,59]$ and integration [60] of HPV 6 and/or HPV 11 genomes have been shown in malignant tissue.

The mere presence of the low-risk HPV 6 and 11 in most of the mamillae and in the concomitant breast carcinoma samples does not prove its role in the aetiology of the disease, although it merits further investigation. Unfortunately, 
Table 2

Presence of HPV DNA: results obtained after amplification with respective primers

\begin{tabular}{|c|c|c|c|c|c|c|c|}
\hline \multirow[t]{2}{*}{ Carcinoma type } & \multirow[t]{2}{*}{ Patient number } & \multirow[t]{2}{*}{ Location } & \multicolumn{2}{|c|}{$\beta$-actin } & \multicolumn{3}{|c|}{ HPV } \\
\hline & & & $\begin{array}{c}\mathrm{KM} 29 / \mathrm{RS} 42 \\
(536 \mathrm{bp})\end{array}$ & $\begin{array}{c}\mathrm{PC0} / \mathrm{PC} 04 \\
(110 \mathrm{bp})\end{array}$ & GP & $\mathrm{CP}$ & FAP \\
\hline \multirow{33}{*}{$\begin{array}{l}\text { Invasive duct } \\
\text { cell }\end{array}$} & 1 & Carcinoma & + & & HPV11 & - & HPV11 \\
\hline & & Nipple & + & & HPV16 & HPV27 & HPV11, HPV57 \\
\hline & 2 & Carcinoma & + & & HPV11 & - & HPV 11 \\
\hline & & Nipple & - & + & HPV11 & - & HPV6, HPV11 \\
\hline & 3 & Carcinoma & + & & - & - & HPV11 \\
\hline & & Carcinoma & + & & HPV16 & HPV27 & - \\
\hline & 4 & Carcinoma & + & & - & - & HPV11 \\
\hline & & Nipple & - & + & - & - & - \\
\hline & 5 & Carcinoma & + & & - & - & HPV 11 \\
\hline & & Nipple & + & & - & - & $\begin{array}{l}\text { HPV3, HPV11, } \\
\text { HPV } 20, \text { HPV } 21\end{array}$ \\
\hline & 6 & Carcinoma & + & & HPV11, HPV16 & $\begin{array}{c}\text { HPV6, HPV27, } \\
\text { HPV57 }\end{array}$ & $\begin{array}{l}\text { HPV3, HPV6, } \\
\text { HPV57 }\end{array}$ \\
\hline & & Nipple & + & & - & - & $\begin{array}{c}\text { HPV6, HPV11, } \\
\text { HPV57 }\end{array}$ \\
\hline & 7 & Carcinoma & + & & - & - & - \\
\hline & & Nipple & + & & - & - & - \\
\hline & 8 & Carcinoma & + & & - & $\begin{array}{l}\text { DL250 (HPV9- } \\
\text { related) }\end{array}$ & - \\
\hline & & Nipple & + & & - & - & - \\
\hline & 9 & Carcinoma & + & & - & $\begin{array}{l}\text { DL473 (HPV15- } \\
\text { related) }\end{array}$ & - \\
\hline & & Nipple & + & & - & - & - \\
\hline & 10 & Carcinoma & + & & - & HPV6 & - \\
\hline & & Nipple & + & & - & - & - \\
\hline & 11 & Carcinoma & + & & - & HPV23 & - \\
\hline & & Nipple & + & & - & $\begin{array}{l}\text { GA3-1 }(\mathrm{HPV} 8- \\
\text { related) }\end{array}$ & - \\
\hline & 12 & Carcinoma & + & & HPV11 & - & - \\
\hline & & Nipple & + & & - & HPV37 & - \\
\hline & 13 & Carcinoma & - & + & HPV11 & - & HPV11 \\
\hline & & Nipple & - & + & - & - & HPV6 \\
\hline & 14 & Carcinoma & - & + & - & HPV 24 & - \\
\hline & & Nipple & + & & - & - & - \\
\hline & 15 & Carcinoma & + & & HPV11 & HPV6, DL250 & HPV11, HPV87 \\
\hline & & Nipple & + & & HPV66 & - & - \\
\hline & 16 & Carcinoma & + & & - & - & HPV 11 \\
\hline & & Nipple & + & & - & - & - \\
\hline & 17 & Carcinoma & + & & - & - & - \\
\hline
\end{tabular}


Table 2 (Continued)

Presence of HPV DNA: results obtained after amplification with respective primers

\begin{tabular}{|c|c|c|c|c|c|c|c|}
\hline & & Nipple & - & + & HPV6, HPV66 & HPV37 & - \\
\hline & 18 & Carcinoma & + & & HPV11 & - & HPV11 \\
\hline & & Nipple & + & & HPV6 & HPV37 & - \\
\hline \multirow[t]{10}{*}{ Medullary } & 19 & Carcinoma & + & & HPV11 & - & HPV11 \\
\hline & & Nipple & - & + & - & - & HPV11 \\
\hline & 20 & Carcinoma & + & & - & - & - \\
\hline & & Nipple & + & & HPV11 & - & - \\
\hline & 21 & Carcinoma & + & & HPV11 & HPV6 & HPV6, HPV87 \\
\hline & & Nipple & + & & - & HPV23 & - \\
\hline & 22 & Carcinoma & + & & HPV11 & HPV6 & HPV6, HPV87 \\
\hline & & Nipple & + & & - & - & - \\
\hline & 23 & Carcinoma & + & & - & HPV 6 & HPV11 \\
\hline & & Nipple & + & & - & - & - \\
\hline \multirow[t]{6}{*}{ Tubular } & 24 & Carcinoma & + & & - & - & HPV57 \\
\hline & & Nipple & - & + & HPV6, HPV57 & HPV6, HPV57 & HPV6, HPV57 \\
\hline & 25 & Carcinoma & + & & - & - & HPV11 \\
\hline & & Nipple & - & + & HPV16, HPV27 & - & HPV11 \\
\hline & 26 & Carcinoma & + & & HPV11 & HPV15 & HPV87 \\
\hline & & Nipple & - & + & - & HPV27, HPV37 & - \\
\hline \multirow[t]{4}{*}{ Lobular } & 27 & Carcinoma & + & & HPV11, HPV16 & HPV27 & - \\
\hline & & Nipple & + & & - & - & HPV 11 \\
\hline & 28 & Carcinoma & + & & - & - & - \\
\hline & & Nipple & + & & - & - & - \\
\hline \multirow[t]{2}{*}{ Mucinous } & 29 & Carcinoma & - & + & - & HPV6 & HPV 11 \\
\hline & & Nipple & + & & - & HPV38 & - \\
\hline
\end{tabular}

bp, base pairs; HPV, human papillomavirus.

Table 3

Papillomavirus sequences demonstrated

\begin{tabular}{lcl}
\hline Tumor pairs & Number & HPV types $^{\mathrm{a}}$ \\
\hline Carcinoma $^{+}$nipple $^{+}$ & 17 & $\begin{array}{l}\text { Same type in both samples: 11 }(7 \times)^{\mathrm{b}}, 6(1 \times)^{\mathrm{b}}, 57(2 \times) \\
\text { Different types: 3, 15, 16, 20, 21, 23, 27, 37, 38, 66, 87, DL250, DL473, GA3-1 }\end{array}$ \\
Carcinoma- nipple $^{+}$ & 3 & $6,11,32,37,66$ \\
Carcinoma $^{+}$nipple & 8 & $6,11,24,87$, DL250, DL473 \\
Carcinoma- nipple- & 1 & \\
\hline
\end{tabular}

alnfection with multiple human papillomavirus (HPV) types was demonstrated in eight carcinoma samples (27.6\%) and ten nipple samples (34.5\%).

bOne pair harboured HPV 6, HPV 11 and HPV 57 DNA. 
Table 4

\begin{tabular}{|c|c|c|c|c|c|c|c|c|c|c|c|}
\hline \multirow[t]{2}{*}{ Carcinoma type } & \multirow[t]{2}{*}{ Location } & \multicolumn{10}{|c|}{ HPV types } \\
\hline & & 6 & 11 & 16 & 27 & 37 & 57 & 66 & 87 & DL250 & Others \\
\hline \multirow[t]{2}{*}{ Intraductal } & Carcinoma & 3 & 11 & 1 & 1 & - & 1 & - & 1 & 2 & $3,23,24, \mathrm{DL} 473$ \\
\hline & Nipple & 5 & 4 & 2 & 2 & 3 & 2 & 2 & - & - & $20,21, \mathrm{GA}-1$ \\
\hline \multirow[t]{2}{*}{ Lobular } & Carcinoma & - & 1 & 1 & 1 & - & - & - & - & - & - \\
\hline & Nipple & - & 1 & - & - & - & - & - & - & - & 32 \\
\hline \multirow[t]{2}{*}{ Tubular } & Carcinoma & - & 2 & - & - & - & 1 & - & 1 & - & 15 \\
\hline & Nipple & 1 & 1 & 1 & 2 & 1 & 1 & - & - & - & - \\
\hline \multirow[t]{2}{*}{ Medullary } & Carcinoma & 3 & 4 & - & - & - & - & - & 2 & - & - \\
\hline & Nipple & - & 2 & - & - & - & - & - & - & - & 23 \\
\hline \multirow[t]{2}{*}{ Mucinous } & Carcinoma & 1 & 1 & - & - & - & - & - & - & - & - \\
\hline & Nipple & - & - & - & - & - & - & - & - & - & 38 \\
\hline \multirow{2}{*}{$\begin{array}{l}\text { Total carcinoma } \\
(\%)\end{array}$} & Carcinoma & $7(24.1)$ & $19(65.5)$ & $2(6.9)$ & 2 & - & 2 & - & $4(13.8)$ & 2 & \\
\hline & Nipple & $6(21)$ & $8(27.6)$ & 3 (10.3) & 4 & 4 & 3 & 2 & - & - & \\
\hline
\end{tabular}

because of the previous fixation of our samples, RNA from these tumours was not available for the detection of viral transcripts as additional support of our results. Relatively few studies have been performed in an attempt to unravel the intracellular mechanisms through which HPV 6 or 11 may immortalise cells, and information is still fractional in comparison with data on the high-risk HPV types. Introduction of the HPV 6 E6 into normal mammary cells leads to immortalisation and reduced levels of the p53 protein [61]. Binding of the HPV 6 E6 protein modulates the function of the cellular proteins Bak [62], Gps2 [63] and Zyxin [64]. Additional in vitro studies investigating the influence of hormones, smoke adducts and genetic factors on the interaction of the HPV 6 and 11 proteins with cellular proteins should provide valuable information on a possible role for HPV 6 and 11 in the pathogenesis of breast carcinoma. The data presented in this study also indicate a strong need for epidemiological studies correlating HPV, cigarette smoking, hormone use and family history to substantiate in vitro findings.

This study suggests that human papillomavirus may infect the epithelium of the nipple and areola. Human papillomavirus infection may be identified with recognisable histological features comparable to human papillomavirus infection at other sites. Furthermore, this study is consistent with a pathogenic mechanism involving transfer in a retrograde fashion via the nipple, areola, lactiferous ducts and sinuses of the human papillomavirus. If confirmed, the pathogenic mechanism proposed may have significant implications for the prevention and treatment of breast carcinoma and the identification of individuals at risk for carcinoma development. Examination of cellular samples of nipple and areola inclusive of cytological examination and methods for identifying the presence of human papillomavirus might aid early diagnosis and perhaps therapy.

\section{Conclusions}

The data demonstrate the occurrence of HPV in nipple and areolar tissues in patients with breast carcinoma. The presence of papillomavirus DNA in most mamillae and concomitant breast carcinoma samples merits further investigation.

\section{Competing interests}

The author(s) declare that they have no competing interests.

\section{Acknowledgements}

We thank Corinne Whitley, Elsbeth Schneider, Romana Cop, Karin Gunst, Helene Rahn and Imke Grewe at the Deutsches Krebsforschungszentrum and Kari Bradshaw, Joyce Kangas and Connie Gibbons at Lower Columbia Pathologists for excellent technical support. This study was supported in part by The Healthcare Foundation, Cowlitz County, Washington. The study was reviewed by the IRB committee at St John Medical Center, Longview, Washington (acting chairperson Dane Moseson MD) and accepted as conforming to the institution's guidelines with regard to retroactive studies employing human tissue samples.

\section{References}

1. Howe HL, Wingo PA, Thun MJ, Ries LAG, Rosenberg HM, Feigal $E G$, Edwards BK: Annual report to the nation on the status of cancers (1973 through 1998), featuring cancers with recent increasing trends. J Natl Cancer Inst 2001, 93:824-842. 
2. Longnecker MP, Bernstein L, Paganini-Hill A, Enger SM, Ross RK: Risk factors for in situ breast cancer. Cancer Epidemiol Biomarkers Prev 1996, 5:961-965.

3. Trentham-Dietz A, Newcomb PA, Storer BE, Remington PL: Risk factors for carcinoma in situ of the breast. Cancer Epidemiol Biomarkers Prev 2000, 9:697-703.

4. Band PR, Nhu DL, Fang R, Deschamps M: Carcinogenic and endocrine disrupting effects of cigarette smoke and risk of breast cancer. Lancet 2002, 360:1044-1049.

5. Brinton L, Lacey J Jr, Devesa SS: Epidemiology of breast cancer. In Cancer of the Breast 5th edition. Edited by: Donegan WL, Spratt JS. London: Saunders Elsevier Science; 2002:111-132.

6. Hamajima N, Hirose K Tajima K, Rohan T, Calle EE, Heath CW Jr, Coates RJ, Liff JM, Talamini R, Chantarakul N, et al.: Alcohol, tobacco and breast cancer - collaborative reanalysis of individual data from 53 epidemiological studies, including 58,515 women with breast cancer and 96,057 women without the disease. Br J Cancer 2002, 87:1234-1245.

7. Hemminki K, Granström C, Czene K: Attributable risks for familial breast cancer by proband status and morphology: a nationwide epidemiologic study from Sweden. Int J Cancer 2002, 100:214-219.

8. zur Hausen $\mathrm{H}$ : Papillomaviruses and cancer: from basic studies to clinical application. Nat Rev Cancer 2002, 2:342-350.

9. Magrath I, Bhatia K: Breast cancer: a new Epstein-Barr virusassociated disease? J Natl Cancer Inst 1999, 91:1349-1350.

10. Wong M, Pagano JS, Schiller JT, Tevethia SS, Raab-Traub N, Gruber J: New associations of human papillomavirus, simian virus 40, and Epstein-Barr virus with human cancer. J Natl Cancer Inst 2002, 94:1832-1836.

11. Wang Y, Pelisson I, Melana SM, Go V, Holland JF, Pogo BG: MMTV-like env gene sequences in human breast cancer. Arch Virol 2001, 146:171-180

12. Zangen R, Harden S, Cohen D, Parrella P, Sidransky D: Mouse mammary tumor-like env gene as a molecular marker for breast cancer? Int J Cancer 2002, 102:304-307.

13. Band V, Zajchowski D, Kulesa V, Sager R: Human papilloma virus DNAs immortalize normal human mammary epithelial cells and reduce their growth factor requirements. Proc Natl Acad Sci USA 1990, 87:463-467.

14. Xu C, Meikrantz W, Schlegel R, Sager R: The human papilloma virus $16 \mathrm{E} 6$ gene sensitizes human mammary epithelial cells to apoptosis induced by DNA damage. Proc Natl Acad Sci USA 1995, 92:7829-7833.

15. Foster SA, Wong DJ, Barrett MT, Galloway DA: Inactivation of p16 in human mammary epithelial cells by $\mathrm{CpG}$ island methylation. Mol Cell Biol 1998, 18:1793-1801.

16. Liu Y, Chen JJ, Gao Q, Dalal S, Hong Y, Mansur CP, Band V, Androphy EJ: Multiple functions of human papillomavirus type $16 \mathrm{E} 6$ contribute to the immortalization of mammary epithelial cells. J Virol 1999, 73:7297-7307.

17. Gao Q, Kumar A, Srinivasan S, Singh L, Mukai H, Ono Y, Wazer $\mathrm{DE}$, Band V: PKN binds and phosphorylates human papillomavirus E6 oncoprotein. J Biol Chem 2000, 275:14824-14830.

18. Helt AM, Funk JO, Galloway DA: Inactivation of both retinoblastoma tumor suppressor and $\mathrm{p} 21$ by the human papillomavirus type $16 \mathrm{E7}$ oncoprotein is necessary to inhibit cell cycle arrest in human epithelial cells. J Viro/ 2002, 76:10559-10568.

19. Di Lonardo A, Venuti A, Marcante ML: Human papillomavirus in breast cancer. Breast Cancer Res Treat 1992, 21:95-100.

20. Hennig EM, Di Lonardo A, Venuti A, Holm R, Marcante ML, Nesland JM: HPV 16 in multiple neoplastic lesions in women with CIN III. J Exp Clin Cancer Res 1999, 18:369-377.

21. Hennig EM, Suo Z, Thoresen S, Holm R, Kvinnsland S, Nesland $\mathrm{JM}$ : Human papillomavirus 16 in breast cancer of women treated for high grade cervical intraepithelial neoplasia (CIN III). Breast Cancer Res Treat 1999, 53:121-135.

22. Yu Y, Morimoto T, Sasa M, Okazaki K, Harada Y, Fujiwara T, Irie $Y$, Takahashi E, Tanigami A, Izumi K: Human papillomavirus type 33 DNA in breast cancer in Chinese. Breast Cancer 2000, 7:33-36.

23. Liu $Y$, Klimberg VS, Andrews NR, Hicks CR, Peng H, Chiriva-Internati $M$, Henry-Tillman R, Hermonat PL: Human papillomavirus DNA is present in a subset of unselected breast cancers. $J$ Hum Virol 2001, 4:329-334.

24. Li T, Lu ZM, Guo M, Wu QJ, Chen KN, Xing HP, Mei Q, Ke Y: p53 codon 72 polymorphism $(\mathrm{C} / \mathrm{G})$ and the risk of human papillo- mavirus-associated carcinomas in China. Cancer 2002, 95:2571-2576.

25. Damin APS, Karam R, Zettler CG, Caleffi M, Alexandre COP: Evidence for an association of human papillomavirus and breast carcinomas. Breast Cancer Res Treat 2004, 84:131-137.

26. Bratthauer GL, Tavassoli FA, O'Leary TJ: Etiology of breast carcinoma: no apparent role for papillomavirus types $6 / 11 / 16$ / 18. Pathol Res Pract 1992, 188:384-386.

27. Wrede D, Lugmani YA, Coombes RC, Vousden KH: Absence of HPV 16 and 18 DNA in breast cancer. $\mathrm{Br} J$ Cancer 1992, 65:891-894

28. Gopalkrishna V, Singh UR, Sodhani P, Sharma JK, Hedau ST, Mandal AK, Das BC: Absence of human papillomavirus DNA in breast cancer as revealed by polymerase chain reaction. Breast Cancer Res Treat 1996, 39:197-202.

29. Lavergne D, de Villiers EM: Papillomavirus in esophageal papillomas and carcinomas. Int J Cancer 1999, 80:681-684.

30. Greer CE, Peterson SL, Kiviat NB, Manos MM: PCR amplification from paraffin-embedded tissues. Anatomic Pathol 1991, 95:117-124.

31. de Roda Husman AM, Walboomers JM, van den Brule AJ, Meijer CJ, Snijders PJ: The use of general primers GP5 and GP6 elongated at their $3^{\prime}$ ends with adjacent highly conserved sequences improves human papillomavirus detection by PCR. $J$ Gen Virol 1995, 76:1057-1062.

32. de Villiers E-M, Lavergne D, McLaren K, Benton EC: Prevailing papillomavirus types in nonmelanoma carcinomas of the skin in renal allograft recipients. Int $J$ Cancer 1997, 73:356-361.

33. Forslund O, Antonsson A, Nordin P, Stenquist B, Hansson BG: A broad range of human papillomavirus types detected with a general PCR method suitable for analysis of cutaneous tumours and normal skin. J Gen Virol 1999, 80:2437-2443.

34. Kawase M, Honda M, Niimura M: Detection of human papillomavirus type 60 in plantar cysts and verruca plantaris by the in situ hybridisation method using digoxigenin labeled probes. $J$ Dermatol 1994, 21:709-715.

35. Zehbe I, Ratsch A, Alunni-Fabbroni M, Burzlaff A, Bakos E, Dürst $\mathrm{M}$, Wilander $\mathrm{E}$, Tommasino M: Overriding of cyclin-dependent kinase inhibitors by high and low risk human papillomavirus types: evidence for an in vivo role in cervical lesions. Oncogene 1999 18:2201-2211.

36. Astori G, Lavergne D, Benton C, Hockmayr B, Egawa K, Garbe C de Villiers E-M: Human papillomaviruses are commonly found in normal skin of immunocompetent hosts. J Invest Dermatol 1998, 110:752-755.

37. de Villiers EM, Lavergne D, Chang F, Syrjanen K, Tosi P, Cintorino $M$, Santopietro R, Syrjanen S: An interlaboratory study to determine the presence of human papillomavirus DNA in esophageal carcinoma from China. Int J Cancer 1999, 81:225-228.

38. de Villiers EM, Gunst K, Stein H, Scherübl H: Esophageal squamous cell cancer in patients with head and neck cancer: prevalence of human papillomavirus DNA sequences. Int J Cancer 2004, 109:253-258.

39. Antonsson A, Forslund O, Ekberg H, Sterner G, Hansson BG: The ubiquity and impressive genomic diversity of human skin papillomaviruses suggest a commensalic nature of these viruses. $J$ Virol 2000, 74:11636-11641.

40. Abramson AL, Nouri M, Mullooly V, Fisch G, Steinberg BM: Latent human papillomavirus infection is comparable in the larynx and trachea. J Med Viro/ 2004, 72:473-477.

41. DeFilippis RA, Goodwin EC, Wu L, DiMaio D: Endogenous human papillomavirus E6 and E7 proteins differentially regulate proliferation, senescence, and apoptosis in HeLa cervical carcinoma cells. J Viro/ 2003, 77:1551-1563.

42. de Villiers EM, Ruhland A, Sekaric P: Human papillomaviruses in non-melanoma skin cancer. Semin Cancer Biol 1999, 9:413-422.

43. de Villiers EM: Human papillomavirus infections in skin cancers. Biomed Pharmacother 1998, 52:26-33.

44. Manavi M, Baghestanian M, Kucera E, Berger A, Schatten C, Pischinger K, Czerwenka K: Papilloma virus and c-erbB-2 expression in diseases of the mammary nipple. Anticancer Res 2001, 21:797-801.

45. Czerwenka K, Heuss F, Hosmann JW, Manavi M, Lu Y, Jelincic D, Kubista E: Human papilloma virus DNA: a factor in the pathogenesis of mammary Paget's disease? Breast Cancer Res Treat 1996, 41:51-57. 
46. Kulke R, Gross GE, Pfister H: Duplication of enhancer sequences in human papillomavirus 6 from condylomas of the mamilla. Virology 1989, 173:284-290.

47. Kowalzick L, Grimmel M, Weyer U, de Villiers EM, Janner M: Recurrent papillomas of the nipple associated with human papillomavirus 41. Br J Dermatol 1990, 122:757-762.

48. de Villiers EM: Human pathogenic papillomavirus types: an update. Curr Top Microbiol Immunol 1994, 186:1-12.

49. zur Hausen $\mathrm{H}$ : Papillomavirus infections - a major cause of human cancers. Biochim Biophys Acta 1996, 1288:F55-F78.

50. de Villiers EM, Weidauer $\mathrm{H}, \mathrm{O}$ to $\mathrm{H}$, zur Hausen $\mathrm{H}$ : Papillomavirus DNA in human tongue carcinomas. Int J Cancer 1985, 36:575-578.

51. Grussendorf-Conen El, Deutz FJ, de Villiers EM: Detection of human papillomavirus- 6 in primary carcinoma of the urethra in men. Cancer 1987, 60:1832-1835.

52. Gissmann L, de Villiers EM, zur Hausen H: Analysis of human genital warts (condylomata acuminata) and other genital tumors for human papillomavirus type 6 DNA. Int J Cancer 1982, 29:143-146.

53. Boshart $\mathrm{M}$, zur Hausen $\mathrm{H}$ : Human papillomavirus in BuschkeLoewenstein tumors: physical state of the DNA and identification of a tandem duplication in the noncoding region of a human papillomavirus 6 subtype. J Virol 1986, 58:963-966.

54. Kasher MS, Roman A: Characterization of human papillomavirus type 6 b DNA isolated from an invasive squamous carcinoma of the vulva. Virology 1988, 165:225-233.

55. Kitasato H, Delius H, zur Hausen H, Sorger K, Rösl F, de Villiers EM: Sequence rearrangements in the upstream regulatory region of human papillomavirus type 6: are these involved in malignant transition? J Gen Virol 1994, 75:1157-1162.

56. Rando RF, Groff DE, Chirikjian JG, Lancaster WD: Isolation and characterization of a novel human papillomavirus type 6 DNA from an invasive vulvar carcinoma. J Virol 1986, 57:353-356.

57. Rosen M, Auborn K: Duplication of the upstream regulatory sequences increases the transformation potential of human papillomavirus type 11. Virology 1991, 185:484-487.

58. McGlennen RC, Ghai J, Ostrow RS, LaBresh K, Schneider JF, Faras AJ: Cellular transformation by a unique isolate of human papillomavirus type 11. Cancer Res 1992, 52:5872-5878.

59. Trujillo JM, Mounts P: Transforming activity of the E6 gene of HPV-11gt in NIH 3T3 and REF 52 cells: correlation with the level of E6 transcription. Virology 1996, 220:1-9.

60. Rady PL, Schnadig VJ, Weiss RL, Hughes TK, Tyring SK: Malignant transformation of recurrent respiratory papillomatosis associated with integrated human papillomavirus type 11 DNA and mutation of p53. Laryngoscope 1998, 108:735-740.

61. Band V, Dalal S, Delmolino L, Androphy EJ: Enhanced degradation of p53 protein in HPV-6 and BPV-1 E6 immortalized human mammary epithelial cells. EMBO J 1993, 12:1847-1852.

62. Thomas M, Banks L: Human papillomavirus (HPV) E6 interactions with Bak are conserved amongst $\mathrm{E} 6$ proteins from high and low risk HPV types. J Gen Virol 1999, 80:1513-1517.

63. Degenhardt YY, Silverstein SJ: Gps2, a protein partner for human papillomavirus E6 proteins. J Viro/ 2001, 75:151-160.

64. Degenhardt YY, Silverstein S: Interaction of Zyxin, a focal adhesion protein, with the E6 protein from human papillomavirus type 6 results in its nuclear translocation. J Virol 2001, 75:11791-11802. 